\title{
MONITORING THE STRUCTURES FROM CARBON EPOXY COMPOSITE USING FIBER BRAGG GRATINGS
}

\author{
GrimberG, R.; SAVIn, A.; Steigmann, R.; BARSANESCU, P.; \\ Curtu, I. \& LEITOIU, B.
}

Abstract: This paper present the use of fiber Bragg gratings embedded in structures from carbon epoxy composites with the aim of monitoring and the prediction of delamination apparition. The apparition of delaminations leads to decreasing of strain for the same load, phenomenon emphasized during the four points bending type testing. The evaluation of the delamination length and therefore over the capability of the structure to resist to subdued loading is made.

Key words: fiber Bragg gratings, carbon epoxy, monitoring, 4 points load, strain
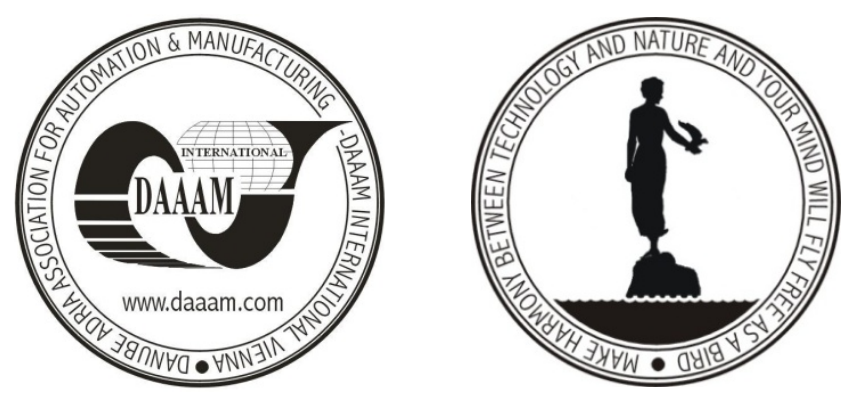

Authors' data: Grimberg, R[aimond]*; Dr. Savin, A[driana]*; Dr. Steigmann, R[ozina]*; Dr. Barsanescu, P[aul]*; Prof. Dr. Eng. Curtu, I[oan]**; Dr. Leitoiu, $\mathrm{B}$ [ogdan]***, *National Institute of Research and Development for Technical Physics, 47 D.Mangeron, 700050, Iasi, RO, **University Transilvania of Brasov, Bdul Eroilor nr 29, Brasov Romania, 500036, Brasov, RO, *** "Gheorghe Asachi" Technical University of Iasi, 5 Canta, bloc 459, sc. A, ap. 15, 700527, Iasi, RO, grimberg@phys-iasi.ro, asavin@phys-iasi.ro, steigmann@phys-iasi.ro, paulbarsanescu@yahoo.com, curtui@unitbv.ro, bleitoiu@yahoo.com

This Publication has to be referred as: Grimberg, R[aimond]; Savin, A[driana]; Steigmann, R[ozina]; Barsanescu, P[aul]; Curtu, I[oan] \& Leitoiu, B[ogdan] (2008). Monitoring the Structures from Carbon Epoxy Composite Using Fiber Bragg Gratings, Chapter 28 in DAAAM International Scientific Book 2008, pp. 325-332, B. Katalinic (Ed.), Published by DAAAM International, ISBN 978-3-901509-66-7, ISSN 1726-9687, Vienna, Austria

DOI: $10.2507 /$ daaam.scibook.2008.28 